\title{
Educational outcomes and socioeconomic status: A decomposition analysis for middle-income countries
}

\section{Sandra Nieto and Raúl Ramos}

\author{
S. Nieto (corresponding author) \\ snietov@uoc.edu \\ Universitat Oberta de Catalunya. Avda. Tibidabo 39-45. 08035 Barcelona. Spain \\ AQR-IREA, University of Barcelona, Avda Diagonal 690, 08034 Barcelona, Spain \\ R. Ramos \\ rramos@ub.edu \\ AQR-IREA, University of Barcelona, Avda Diagonal 690, 08034 Barcelona, Spain
}

\begin{abstract}
This article analyzes the factors that explain the gap in educational outcomes between the top and bottom quartile of students in different countries, according to their socioeconomic status. To do so, it uses PISA microdata for 10 middle-income and 2 high-income countries, and applies the Oaxaca-Blinder decomposition method. Its results show that students' individual variables only explain differences in high-income countries; meanwhile, school and teacher quality, and better practices, matter even in different institutional settings. From a policy perspective, this evidence supports actions to improve school and teacher quality in order to reduce cross-country differences and differences between students at the top and bottom of socioeconomic distribution.
\end{abstract}

Keywords: Educational outcomes, socioeconomic status, PISA, decomposition methods, middle-income countries

This article builds on Nieto and Ramos (2013). We are grateful to the members of the EFA Global Monitoring Report team and the editors and referees of Prospects for their constructive and helpful comments and suggestions. We especially acknowledge Manos Antoninis, Kwame Akyeampong, and Pauline Rose. 
Although students' academic results have been improving in recent years in most countries, socioeconomic status remains a strong predictor of performance (OECD 2010). Students who are socioeconomically advantaged perform better than lessadvantaged students. Family socioeconomic status can affect students' performance in different ways; however, empirical researchers have struggled to disentangle the real contributions of other factors that can also be correlated with family background. For this reason, in this article we deviate from the usual approach and do not include socioeconomic status as a determinant of educational outcomes in an educational production function. We consider this variable only to classify students into two groups: those at the top of the socioeconomic status distribution and those at the bottom.

Our objective is to analyze the factors underlying the gaps in educational outcomes between the top and bottom quarter of students, according to their socioeconomic status, in various middle-income countries. We focus on middle-income countries from five regions: Arab States (Jordan and Tunisia), Central Asia (Azerbaijan and Kyrgyzstan), Central and Eastern Europe (Russian Federation and Turkey), East Asia (Indonesia and Thailand), and Latin America (Brazil and Mexico). We also include two high-income countries in Western Europe (the Netherlands and the United Kingdom) to compare the possible differences in students' outcomes between middleand high-income countries - an issue widely considered in the literature since Heyneman and Loxley's (1983) seminal study. Although PISA surveys provide data for many countries, we focus on this small sample of economies because they are representative of areas with divergent societies and educational systems, which scholars have rarely studied from this perspective.

We find that although important differences exist in students' socioeconomic status between high- and middle-income countries, the factors that explain differences in educational outcomes within countries are quite similar. Applying the OaxacaBlinder decomposition method, we suggest that school variables are the most important factor in learning outcomes amongst students of different socioeconomic status. Likewise, variables related to teacher quality are important in most countries, but the effect of these variables is quite small compared to that of school variables. 


\section{Context}

Most researchers on the determinants of student outcomes agree that parents' characteristics are the most important predictors of success at school (Coleman et al. 1966; Feinstein and Symons 1999; Haveman and Wolfe 1995). That is, the higher the family's socioeconomic level, the better the student does educationally. However, as we mentioned above, family socioeconomic status affects student performance in different ways. Moreover, it is not the only factor that does so: individual, school, and teacher characteristics are also relevant (see, for instance, Hanushek and Woessmann 2011a, 2011b).

The first group of variables - individual characteristics - includes the student's gender, age, country of origin, and native language. For instance, Marks (2008) shows that boys tend to outperform girls in mathematics, while the results for reading are the opposite. Regarding nationality, researchers report that immigrants do not score as well on tests as do native students (Chiswick and DebBurman 2004; Meunier 2011). In regard to language, some have found evidence that immigrants improve their academic outcomes when they speak the official language of the country where they have settled (Entorf and Minoiu 2005).

School characteristics, the second group of variables, include location, type (public or private), size, and teacher-student ratio. The consensus among academics analyzing the influence of school characteristics is not as strong as the consensus for individual characteristics. Such scholars as Coleman and Hoffer (1987), Hanushek (1986), Opdenakker and Van Damme (2006), Stevans and Sessions (2000), and Vandernberghe and Robin (2004) find that students attain better outcomes in private than in public schools. Yet others, including Fertig (2003), Noell (1982), Sander (1996), Smith and Naylor (2005), and Somers, McEwan, and Willms (2004), report no effect of school type on student outcomes. Likewise, the effect that school size has on student outcomes is unclear. While Barnett, Glass, Snowdon, and Stringer (2002) found a positive relationship between school size and learning, Hanushek and Luque (2003) did not see this variable having a significant impact in the majority of countries they analyzed. Results regarding the number of students per teacher are similarly inconclusive. Arum (2000) and Krueger (2003) found that students perform better in small classes, while Hanushek (2003) and Rivkin, Hanushek, and Kain (2005) did not 
find the variable had any statistically significant effect on students' educational outcomes. Boarini and Lüdemann (2009) analyzed the impact of school accountability, school autonomy, and spending on the quality of learning. They found evidence that some accountability policies at the school and national levels increase student achievement, but found no influence that school autonomy had an impact on students' test scores. Finally, it is worth mentioning that several scholars also highlight the influence peers can have on educational outcomes (see, for instance, Hanushek, Kain, Markman, and Rivkin 2003).

Regarding the factor of teacher quality, Dolton and Marcerano-Gutierrez (2011) considered the determinants of teachers' salaries across countries and examined the relationship between teacher remuneration and students' educational performance, analyzing panel data on 39 countries. Their results suggest that recruiting higher-ability individuals into teaching and permitting scope for faster salary advancement will have a positive effect on pupil outcomes. Woessmann (2011) and Boarini and Lüdemann (2009) obtained similar results. Current empirical evidence also suggests the relevance of the teacher-student relationship. In particular, Lee (2012) found an association between students' perceptions of the school social environment and their test scores.

Although recent theoretical contributions emphasize the important effects that institutional school systems can have on educational performance (Bishop and Woessmann 2004), empirical analyses show that these effects should mainly be an issue in cross-country rather than within-country research (Fuchs and Woessmann 2007).

Most comparative analyses of educational performance have focused on developing countries. For example, Woessmann (2010) compared determinants in Latin American countries to those of similar countries in Eastern Europe and more industrialized countries in Western Europe. He found strong evidence of associations between students' educational performance and their family background characteristics, but the results with respect to school characteristics were inconsistent. Ammermueller, Heijke, and Woessmann (2005) analyzed determinants of schooling quality for seven Eastern European transition countries and compared the results with some Western European countries. They found that the effects of family background characteristics are consistently greater in countries that introduced reforms earlier to their education systems. Furthermore, students from countries that introduced reforms later do less well on tests but have more equal opportunities since they are less affected by family background. 
Finally, some researchers applied decomposition methods in educational outcomes, including Ammermueller (2007), Baird (2012), Burger (2011), Ramos, Duque, and Nieto (2012), and Zhang and Lee (2011).

\section{Data and methodological approach}

\section{Data}

The data source we used in this study is the Programme for International Student Assessment (PISA), which assesses students from a number of countries at the end of compulsory education (age 15) in the subjects of mathematics, science, and reading. PISA also provides information about the students, their family backgrounds, and the learning environment of their schools. Furthermore, the 2006 and 2009 surveys include specific information about student perceptions of teachers of science and reading, respectively. To take into account those variables related to teachers, we carried out the analysis using this specific data.

Regarding the variable of interest, we used the index of economic, social, and cultural status (ESCS), which takes into account students' backgrounds. ESCS allows us to classify students depending on their socioeconomic status, identifying the higher and lower quartiles.

As explanatory variables, we also included the following ones provided in the survey (see appendix for more detail). For individual characteristics we considered gender, age, nationality (native, and first- and second-generation immigrants), family structure (nuclear, single parent, and mixed family; only for 2009), an index related to the student's interest in learning science (only for 2006), and an index of attitudes toward school (only for 2009). For teacher quality, we included some indices built from students' perceptions about teachers that differ between 2006 and 2009. Indicators for 2009 include teacher-student relationship, disciplinary climate, and teachers' ability to stimulate and motivate students' reading engagement. Indicators for 2006 are more focused on science, including interaction between students and teachers in science class, hands-on activities in science class, frequency of student investigations in science class, and frequency of teaching in science lessons with a focus on applications. Finally, we took account of variables related to the school, including its location (urban or rural), size, student-teacher ratio, whether it is public or private. And we included such other 
variables as whether the school sorts students into classes based on ability, computer availability, educational resources, extra-curricular activities, school principal's leadership (not for 2006), school responsibility for curriculum and assessment, school responsibility for resource allocation, computers connected to the Internet, and academic selectivity.

Although many researchers use PISA data to identify the factors contributing to improvements in student outcomes, these data are not without critics. A primary shortcoming is that PISA focuses on 15-year-old students, so one cannot generalize conclusions for a country's education system. PISA also considers the 15-year-old population that is enrolled in the education system, and this percentage could vary depending on the country (OECD 2009). For example: as of 2006, the enrolment percentages for each country included in this study were as follows: Jordan 65\%, Tunisia 90\%, Azerbaijan 88\%, Kyrgyzstan 63\%, Russian Federation 81\%, Turkey 47\%, Indonesia 53\%, Thailand 72\%, Brazil 55\%, Mexico 54\%, the Netherlands 96\%, and the United Kingdom 94\%.

Thus, the sample coverage rate of PISA data is not representative for some countries (Ferreira and Gignoux 2011). Despite these limitations, PISA is the only dataset that allows us to compare worldwide educational systems by means of the same variables and indicators in terms of both inputs and outputs.

\section{Methodological approach}

As mentioned, our objective is to explain the gap in scores between the top and bottom quartile of students according to their ESCS index in each country. To do so, we apply the Oaxaca-Blinder decomposition technique (Blinder 1973; Oaxaca 1973). The relative advantage of this method is that it permits us to identify which part of the gap is due to differences in the determinants of the outcome, and which is due to differences in the effects of these determinants - an aspect that we cannot easily consider in a regression framework. One peculiarity of our analysis when compared to other applications of the Oaxaca-Blinder method is that we define the groups to be compared in terms of a continuous variable (ESCS) instead of a discrete variable (i.e., male/female; white/black). Although not frequently used, this approach is not unique in the literature. For instance, Frenette (2007) has analyzed differences in university attendance using income quartiles to define the groups to be compared. While other decomposition 
methods could have been applied, Nopo (2008) and Ulrick (2012) have shown, from a methodological perspective, that the Oaxaca-Blinder decomposition technique is valid when one uses a continuous variable to define the groups.

We base this procedure on the estimations of the following educational production functions for each group of interest:

$$
\text { RTest }_{i}=\alpha+\beta \cdot Z_{i}+e_{i}
$$

where RTest $_{i}$ is the dependent variable referring to the five plausible values of the test results in each subject area (science in 2006 and reading in 2009) for student $i ; Z_{i}$ is a vector of control variables related to the characteristics of the individuals, teachers, and school environment; and $e_{i}$ is a random-error term. Plausible values are not the students' actual test scores; they are random numbers drawn from the distribution of scores that could be reasonably assigned to each individual. Mislevy and Sheehan $(1987,1989)$ developed this methodology, based on Rubin's (1987) theory for imputing missing or lost values. The idea is that individuals respond to a limited number of test questions, so one must estimate their behaviour as if they had answered all the questions. To do this, one predicates their results using both their actual responses to questions and other variables from the context questionnaire. Instead of a single score, this method generates a distribution of values for each individual with their associated probabilities, and randomly obtains five plausible values for each individual—avoiding the bias introduced when estimating the outcomes from a small number of test questions. Plausible values contain random-error variance components and are not optimal as individual test scores. Thus, although unsuitable for diagnosing subjects, they are well suited to the consistent estimation of population parameters.

Additionally, due to PISA's complex sample design, we have to apply a replication procedure to calculate the variance of the estimators. In particular, we follow the OECD (2009), which recommends the Fay-modified Balanced Repeated Replication (BRR) method (Fay 1989), which improves the accuracy of the variance estimator without modifying the coefficients. ${ }^{1}$ To do so we employed the Stata module for performing estimations, available at http://ideas.repec.org/c/boc/bocode/s456951.html.

\footnotetext{
1 The OLS estimation of educational production functions could be affected by several potential econometric caveats including multicollinearity or nonlinearities. Detailed results of the estimates and diagnostic tests are available from us upon request.
} 
Taking into account previous results, the Oaxaca-Blinder technique breaks down, into two parts, the difference in educational outcomes between students at the top and bottom of the ESCS index distribution: one part explained by group differences in observed characteristics, and one caused by differences in outcomes associated with these characteristics:

$$
\overline{\operatorname{RTest}}_{T}-\overline{\operatorname{RTest}}_{B}=\left(\bar{Z}_{T}-\bar{Z}_{B}\right) \cdot \beta_{B}+\bar{Z}_{B} \cdot\left(\beta_{T}-\beta_{B}\right)+\left(\bar{e}_{T}-\bar{e}_{B}\right)
$$

where the subindexes $T$ and $B$ correspond to the top and bottom quartile students respectively. ${ }^{2}$ Equation (2) enables us to quantify the extent to which the cause of the differences between these two groups of students is related to differences observed in individual factors - the school and teaching environment — or the influence of unobserved factors. More specifically, the first term on the right-hand side of the equation corresponds to that part of the differential in educational performance attributable to group differences in observed characteristics, coinciding with the "explained" component of the Oaxaca-Blinder decomposition. The second and third terms correspond, respectively, to the difference in coefficients and differences in unobservable skills, capturing the discriminatory or "unexplained" component of this decomposition.

\section{Results}

\section{Descriptive statistics on students' score gaps}

Figure 1 compares the average in scores between students at the top and bottom quartiles of the ESCS distribution (and the difference) by country and subject (sciences and reading). Descriptive statistics of the remaining variables for the 12 considered countries are available upon request.

\footnotetext{
2 Different break points have been considered to define the groups. In particular, decompositions for differences between the fourth and the third quartile, between the fourth and the second quartile, between the fourth and the first quartile, between the third and the second quartile, between the third and the first quartile, and between the second and the first quartile have also been considered. Results, which are available from the authors on request, show two interesting facts: first, that greater differences in educational outcomes are associated with differences between the fourth and the first quartile of income in all countries, and second, that the relative contribution of personal, school, and individual characteristics to explain educational outcomes are similar across the ESCS distribution.
} 
[Figure 1 around here]

As the figure shows, students in the UK and the Netherlands have the highest scores in both groups. It is worth noting that the average scores in both science and reading for the top quartile of the ESCS distribution of students in Brazil, Indonesia, Azerbaijan, Kyrgyzstan, Tunisia, and Jordan are below the average score for the bottom quartile in the two high-income countries we also consider. Regarding differences in educational achievement within countries, our analysis of data in both subjects found that differences are small in Indonesia and Azerbaijan, whereas they are quite important in the UK, the Netherlands, Brazil, and Mexico. The case of Kyrgyzstan is especially interesting, given that the difference between students in reading in 2009 is almost twice the difference in science in 2006.

\section{Factors explaining the gap in mean scores}

Table 1 shows the results of the Oaxaca-Blinder decomposition. The endowments of observable characteristics of the two considered groups of students explain approximately half of the difference between them, both in science (2006) and reading (2009), but the results are heterogeneous among countries.

[Table 1 around here]

In particular, and in relation to science (2006), in Tunisia, Azerbaijan, Kirgizstan, Turkey, Indonesia, Thailand, Brazil, Mexico, and the Netherlands, differences in characteristics account for more than half the raw difference in scores between students in the top and bottom parts of the ESCS distribution. In Jordan, Russia, and the UK, differences in characteristics are relevant but only explain about one third of the observed difference. For reading (2009), the share explained by differences in characteristics is smaller, although for some countries-including Azerbaijan, Indonesia, Thailand, Brazil, and Mexico - the contribution is still above $50 \%$. As in all cases, the sign of the explained component is negative, and endowments on observed characteristics contribute to increasing the gap in scores between both groups of students. This means that if students with lower ESCS were identical in the 
endowments of observed characteristics to the students with higher ESCS, a significant part of the observed gap in the scores would disappear.

When we break down the "explained component" in terms of individual, school, and teacher characteristics, we find that individual characteristics have less explanatory power than school and teacher quality. However, individual characteristics are more important in high-income countries (the Netherlands and the UK) than in the other countries we analyzed. School factors are the most relevant, both for science and reading, in all countries. Variables related to teacher quality seem to be more relevant for science than for reading, but their relative importance is considerably lower than school variables in all countries, except Azerbaijan.

Regarding individual variables, interest in science is the most influential variable for 2006 data. For instance, in the Netherlands and the UK, approximately 10 points of the observed gap could be reduced if students at the bottom of the ESCS distribution had the same interest in science as students in the upper quartile. For Jordan and Turkey, the reduction would be around 5 points, while for Azerbaijan, Indonesia, and Mexico it would be lower (between 1 and 2 points). Moving to 2009 data, individual characteristics are less relevant in explaining the gap in reading scores. The most influential variables are gender and family type. Attitude toward school is also relevant for some countries; the elimination of differences in attitude toward school between the two groups of students in Turkey and Mexico would reduce the gap by more than 2 points.

As for school characteristics, the most relevant variables within this group are school size, school educational resources, activities to promote science, and extracurricular activities. School size is clearly the most influential variable within this group, particularly for reading scores in 2009. If differences in this variable between the two groups disappeared, the gap would be reduced by around 10 points in Tunisia, Russia, Thailand, and the Netherlands.

Regarding variables related to teacher quality, the most relevant when looking at science scores in 2006 are the frequency of teaching in science lessons with a focus in applications (Jordan, Brazil, Mexico, and the Netherlands) and frequency of students' investigations in science (most of the countries considered). When we look at reading scores in 2009, the most relevant variable is stimulus to read. In this case, if both groups of students received the same stimulus from teachers, the gap would be about 2 percentage points. 
Finally, it is worth mentioning that the rest of the gap (usually labelled "unexplained") is associated with the different effects of the considered variables on educational outcomes. We conducted a more detailed analysis of this, which we cannot include here given space constraints, but will provide on request. From this analysis, we found that between $80 \%$ and $90 \%$ of the differential effect of the explanatory variables is associated with individual variables, while school variables and teacher quality play only a minor role. Thus, students with the same individual characteristics score differently on tests depending on their socioeconomic backgrounds. However, no differences appear in the "returns" to educational resources between students at the top and bottom of the ESCS distribution. In other words, all students respond similarly to improvements in school or teacher variables, regardless of their socioeconomic status.

\section{Conclusions}

Our objective was to analyze the gap in scores between the top and bottom quartile of students according to their socioeconomic status in a set of countries, comparing middle- and high-income countries. To do so, we applied the Oaxaca-Blinder decomposition method using PISA data for 2006 and 2009.

In analyzing our results, we found that endowments on observable characteristics explained approximately half of the differences between students in the bottom and top quartiles of the ESCS distribution in almost all countries in both years. If students in the bottom quartile had the same endowment characteristics as students in the top quartile, their differences in educational outcomes would halve.

Variables related to better practices in school and teacher quality are the most important in explaining differences in educational outcomes between students according to their socioeconomic status in all countries, regardless of their institutional settings. In particular, we found a group of variables that reduce the gap between more-favoured and less-favoured students in terms of socioeconomic characteristics. These are related to interest in science, positive attitude toward school, school size and better educational resources, more activities to promote science, and extracurricular activities, together with efforts to teach science with a focus on applications and a higher stimulus to read.

From a policy perspective, this evidence shows that regardless of the differences between the socioeconomic levels of students between countries, policymakers should take similar actions to reduce differences within countries. For instance, actions 
addressed at improving practices at schools (more resources to improve school climate and students' interest in school) and teacher quality would be important in reducing differences in learning outcomes between students. It is worth mentioning, however, that although our analysis controls for family socioeconomic status, parental background can also affect school choice and, as a result, our analysis provides an upper boundary on school impact.

\section{References}

Ammermueller, A. (2007). PISA: What makes the difference? Explaining the gap in test scores between Finland and Germany. Empirical Economics, 33(2), 263-287.

Ammermueller, A., Heijke, H., \& Woessmann, L. (2005). Schooling quality in Eastern Europe: Educational production during transition. Economics of Education Review, 24, 579-99.

Arum, R. (2000). Schools and communities: Ecological and institutional dimensions. Annual Review of Sociology, 26, 395-418.

Baird, K. (2012). Class in the classroom: The relationship between school resources and math performance among low socioeconomic status students in 19 rich countries. Education Economics, 20(5), 484-509.

Barnett, R. R., Glass, J. C., Snowdon, R. I., \& Stringer, K. S. (2002). Size, performance and effectiveness: Cost-constrained measures of best-practice performance and secondary-school size. Education Economics, 10(3), 291-311.

Bishop, J. H., \& Woessmann, L. (2004). Institutional effects in a simple model of educational production. Education Economics, 12, 17-38.

Blinder, A. S. (1973). Wage discrimination: Reduced form and structural variables. Journal of Human Resources, 8, 436-455.

Boarini, R., \& Lüdemann, E. (2009). The role of teacher compensation and selected accountability policies for learning outcomes: An empirical analysis for OECD countries. OECD Journal: Economic Studies, 2009(1), 211-230.

Burger, R. (2011). School effectiveness in Zambia: The origins of differences between rural and urban outcomes. Development Southern Africa, 28(2), 157-176.

Chiswick, B. R., \& DebBurman, N. (2004). Educational attainment: Analysis by immigrant generation. Economics of Education Review, 23, 361-379. 
Coleman, J. S., \& Hoffer, T. (1987). Public and private high schools: The impact of communities. New York: Basic Books.

Coleman, J. S., Campbell, J. S., Campbell, E. Q., Hobson, C. J., McPartland, J., Mood, A. M., . . \& \& York, R. L. (1966). Equality of educational opportunity. Washington, DC: US Department of Health, Education, and Welfare.

Dolton, P., \& Marcenaro-Gutierrez, O. D. (2011).If you pay peanuts do you get monkeys? A cross-country analysis of teacher pay and pupil performance. Economic Policy, 26(65), 5-55.

Entorf, H., \& Lauk, M. (2008). Peer effects, social multipliers and migrants at school: An international comparison. Journal of Ethnic and Migration Studies, 34(4), 633-654.

Entorf, H., \& Minoiu, N. (2005). What a difference immigration policy makes: A comparison of PISA scores in Europe and traditional countries of immigration. German Economic Review, 3, 355-376.

Fay, R. E. (1989). Theoretical application of weighting for variance calculation. Proceedings of the Section on Survey Research, pp. 212-217. Alexandria: American Statistical Association.

Feinstein, L., \& Symons, J. (1999). Attainment in secondary education. Oxford Economic Papers, 51, 300-321.

Ferreira, F., \& Gignoux, J. (2011). The measurement of educational inequality: Achievement and opportunity. Working Paper 240ECINEQ Society for the Study of Economic Inequality.

Fertig, M. (2003). Who's to blame? The determinants of German students' achievement in the PISA 2000 study. IZA Discussion Paper Series 739. Bonn: IZA, Institute for the Study of Labor.

Frenette, M. (2007), Are youth from lower-income families less likely to attend university? Evidence from academic abilities, parental influence, and financial constraints. Ottawa: Statistics Canada, Ministry of Industry.

Fuchs, T., \& Woessmann, L. (2007). What accounts for international differences in student performance? A reexamination using PISA data. Empirical Economics, $32(2-3), 433-462$.

Hanushek, E. A. (1986). The economics of schooling. Journal of Economic Literature, $24,1141-1177$. 
Hanushek, E. A. (2003). The failure of input based schooling policies. Economic Journal, 113, 64-98.

Hanushek, E. A., \& Luque, J. A. (2003). Efficiency and equity in schools around the world. Economics of Education Review, 22, 481-502.

Hanushek, E. A., Kain, J. F., Markman, J. M., \& Rivkin, S. G. (2003). Does peer ability affect student achievement? Journal of Applied Econometrics, 18, 527-544.

Hanushek, E. A., \& Woessmann, L. (2011a). How much do educational outcomes matter in OECD countries? Economic Policy, 26(67), 427-491.

Hanushek, E. A., \& Woessmann, L. (2011b). The economics of international differences in educational achievement. In E. A. Hanushek, S. Machin, \& L. Woessmann (Eds.), Handbook of the economics of education, vol. 3 (pp. 89200). Amsterdam: North Holland.

Haveman, R., \& Wolfe, B. (1995). The determinants of children's attainment: A review of methods and findings. Journal of Economics Literature, 33(4), 1829-1878.

Heyneman, S. P., \& Loxley, W. A. (1983). The distribution of primary school quality within high- and low-income countries. Comparative Education Review, 27(1), $108-118$.

Krueger, A. B. (2003). Economics considerations and class size. Economic Journal, $113,34-63$.

Lee, J-S. (2012). The effects of the teacher-student relationship and academic press on student engagement and academic performance. International Journal of Educational Research, 53, 330-340.

Marks, G. N. (2008). Accounting for the gender gaps in student performance in reading and mathematics: Evidence from 31 countries. Oxford Review of Education, 34(1), 89-109.

Meunier, M. (2011). Immigration and student achievement: Evidence from Switzerland. Economics of Education Review, 30(1), 16-38.

Mislevy, R. J., \& Sheehan, K. M. (1987). Marginal estimation procedures. A.E, Beaton (Ed.), The NAEP 1983-84 technical report, National Assessment of Educational Progress (pp. 293-360). Princeton, NJ: Educational Testing Service.

Mislevy, R. J., \& Sheehan, K. M. (1989). Information matrices in latent-variable models. Journal of Educational Statistics, 14, 335-350.

Nieto, S., \& Ramos, R. (2013). Decomposition of differences in PISA results in middle-income countries. Background paper for the 2013 Education for All 
Global Monitoring Report: Teaching and learning: achieving quality for all. Paris: UNESCO.

Noell, J. (1982). Public and Catholic schools: A re-analysis of public and private schools. Sociology of Education, 55, 123-132.

Ñopo, H. (2008). An extension of the Blinder-Oaxaca decomposition to a continuum of comparison groups. Economics Letters, 100, 292-296.

Oaxaca, R. (1973). Male-female wage differentials in urban labor markets. International Economic Review, 14(3), 139-148.

OECD [Organisation for Economic Cooperation and Development] (2009). Technical report 2006. Paris: OECD.

OECD (2010). PISA 2009 results: Overcoming social background-Equity in learning opportunities and outcomes. Vol. 2. http://dx.doi.org/10.1787/9789264091504en

Opdenakker, M. C., \& Van Damme, J. (2006). Differences between secondary schools: A study about school context, group composition, school practice, and school effects with special attention to public and Catholic schools and types of schools. School Effectiveness and School Improvement, 17(1), 87-117.

Ramos, R., Duque, J. C., \& Nieto, S. (2012). Decomposing the rural-urban differential in student achievement in Colombia using PISA microdata. IZA discussion paper no. 6515. Bonn: IZA, Institute for the Study of Labor.

Rivkin, S. G., Hanushek, E. A., \& Kain, J. F. (2005). Teachers, schools and academic achievement. Econometrica, 73(2), 417-458.

Rubin, D. B. (1987). Multiple imputation for nonresponse in surveys. New York: Wiley.

Sander, W. (1996). Catholic grade schools and academic achievement. Journal of Human Resources, 31(3), 540-548.

Somers, M. A., McEwan, P. J., \& Willms, J. D., 2004. How effective are private schools in Latin America? Comparative Education Review, 48(1), 48-69.

Smith, J., \& Naylor, R. A. (2005). Schooling effects on subsequent university performance: Evidence for the UK university population. Economics of Education Review, 24, 549-562.

Stevans, L. K., \& Sessions, D. N. (2000). Private/public school choice and student performance revisited. Education Economics, 8(2), 169-184.

Ulrick, S. W. (2012). The Oaxaca decomposition generalized to a continuous group variable. Economics Letters, 115, 35-37. 
Vandernberghe, V., \& Robin, S. (2004). Evaluating the effectiveness of private education across countries: A comparison of methods. Labor Economics 11(4), 487-506.

Woessmann, L. (2010). Families, schools, and primary-school learning: Evidence for Argentina and Colombia in an international perspective. Applied Economics, 42(21), 2645-2665.

Woessmann, L. (2011). Cross-country evidence on teacher performance pay. Economics of Education Review, 30(3), 404-418.

Zhang, L., \& Lee, K. A. (2011). Decomposing achievement gaps among OECD countries. Asia Pacific Education Review 12(3), 463-474. 


\section{Tables and figures}

Figure 1 Differences in educational outcomes in science in 2006 and reading in 2009 between high ESCS (q75) and low ESCS (q25)

students

Average score for high ESCS (q75) and low ESCS (q25) students in science in 2006

Average score for high ESCS (q75) and low ESCS (q25) students in

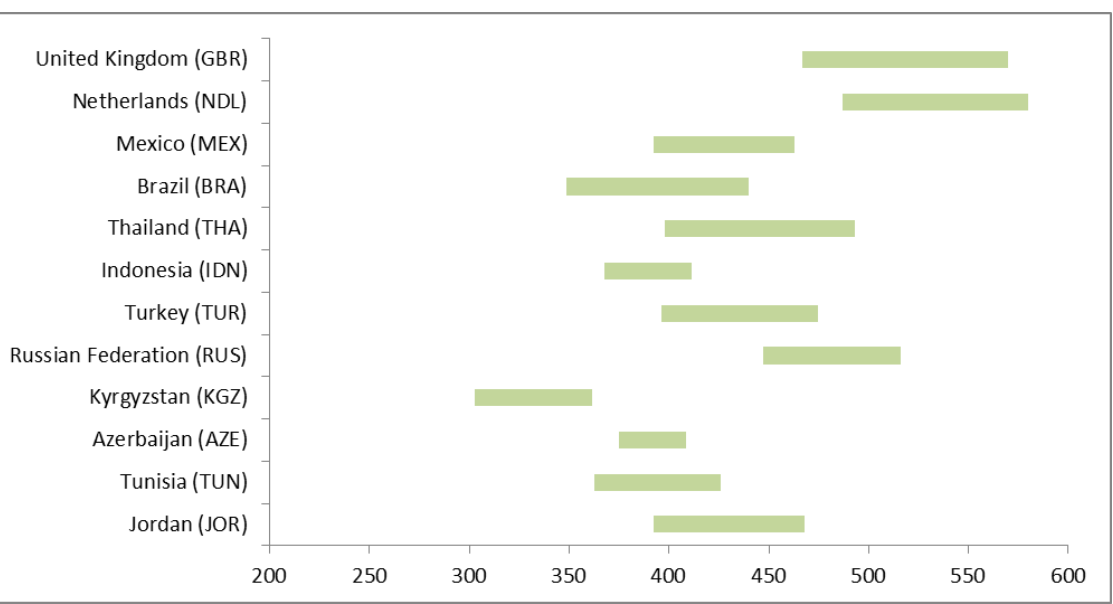
reading in 2009

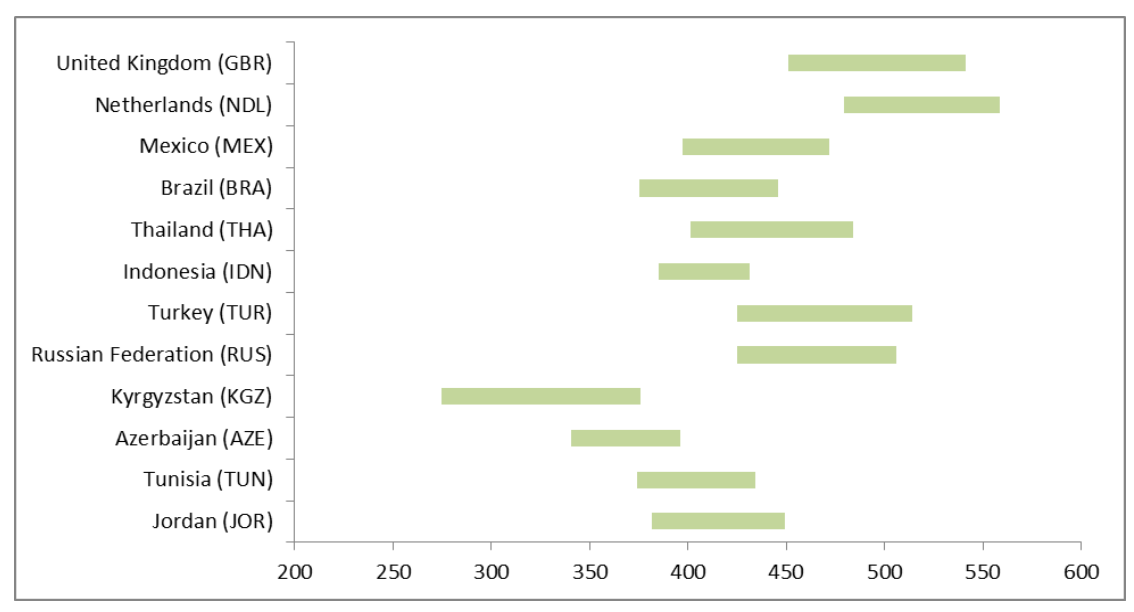


Table 1 Oaxaca-Blinder decomposition between high ESCS (q75) and low ESCS (q25) students in scores for science in 2006 and reading in 2009. Detailed results for the explained component $(1 / 2)$.

\begin{tabular}{|c|c|c|c|c|c|c|c|c|c|c|c|c|}
\hline Science 2006 & JOR & TUN & $\mathbf{A Z E}$ & KGZ & RUS & TUR & IDN & THA & BRA & MEX & NLD & GBR \\
\hline ESCS25 & 392.9 & 369.7 & 398.0 & 307.6 & 447.4 & 396.1 & 376.6 & 397.4 & 364.8 & 382.6 & 492.6 & 470.2 \\
\hline ESCS75 & 471.4 & 425.9 & 412.5 & 376.0 & 519.6 & 478.4 & 430.2 & 480.2 & 457.4 & 471.1 & 585.2 & 576.7 \\
\hline Difference & $-78.43 * * *$ & $-56.20 * * *$ & -14.48 & $-68.33 * * *$ & $-72.26 * * *$ & $-82.25 * * *$ & $-53.57 * * *$ & $-82.81 * * *$ & $-92.63 * * *$ & $-88.48 * * *$ & $-92.59 * * *$ & $-106.4 * * *$ \\
\hline Unexplained & $-56.70 * * *$ & $-24.25 * * *$ & 3.002 & $-27.06 * * *$ & $-51.78 * * *$ & $-38.88 * * *$ & $-14.61 * * *$ & $-27.71 * * *$ & $-34.12 * * *$ & $-34.47 * * *$ & $-44.62 * * *$ & $-70.79 * * *$ \\
\hline Explained & $-21.73 * * *$ & $-31.95 * * *$ & $-17.48 * *$ & $-41.27 * * *$ & $-20.47 * * *$ & $-43.38 * * *$ & $-38.96 * * *$ & $-55.10 * * *$ & $-58.52 * * *$ & $-54.01 * * *$ & $-47.97 * * *$ & $-35.62 * * *$ \\
\hline Individual variables & -2.191 & -0.317 & -2.144 & -1.357 & $-4.730 * * *$ & $-5.316 * * *$ & $-2.128 * *$ & $-3.945 * * *$ & -0.463 & -0.929 & $-16.04 * * *$ & $-13.16 * * *$ \\
\hline Female & 0.842 & 0.0318 & -0.169 & -0.331 & -0.111 & -0.64 & -0.263 & -0.1 & -0.62 & -0.0465 & -0.276 & -0.148 \\
\hline Age & 0.0808 & -0.0516 & -0.00521 & -0.112 & -0.452 & $-0.766^{*}$ & 0.6 & $-1.431 * *$ & 0.164 & -0.0967 & 0.0355 & -0.0336 \\
\hline Immigrant 1 st gen. & $1.709 * * *$ & -0.0881 & 0.00796 & -0.0538 & -0.0437 & -0.0187 & -0.179 & -0.0382 & -0.0262 & -1.143 & -0.995 & -0.0149 \\
\hline Immigrant 2nd gen. & -0.299 & -0.0466 & 0.0374 & $-0.970 * *$ & -0.124 & 0.11 & 0 & 0.123 & -0.687 & -0.317 & -3.373 & -0.367 \\
\hline Language & 0.342 & 1.188 & -0.434 & -0.0304 & $-4.340 * *$ & 0.498 & -0.175 & -1.357 & -0.0522 & -0.0433 & -1.507 & -0.747 \\
\hline Interest in Science & $-4.866 * * *$ & -1.351 & $-1.581 * *$ & 0.14 & 0.34 & $-4.498 * * *$ & $-2.110 * * *$ & -1.142 & 0.758 & $0.717 *$ & $-9.926 * * *$ & $-11.85 * * *$ \\
\hline School variables & $-16.99 * * *$ & $-27.95 * * *$ & -8.305 & $-26.54 * * *$ & $-9.896 * * *$ & $-35.05 * * *$ & $-33.60 * * *$ & $-51.15 * * *$ & $-55.45 * * *$ & $-49.21 * * *$ & $-27.22 * * *$ & $-18.87 * * *$ \\
\hline Rural & -3.559 & -4.236 & -0.753 & $-13.47 * * *$ & $-5.891 *$ & -0.165 & -5.255 & $-10.94 * *$ & 1.894 & $-9.576^{*}$ & -0.0951 & -1.311 \\
\hline Private & $-10.47 * * *$ & 2.06 & -0.861 & -2.71 & 0 & 0.907 & 0.452 & 1.762 & $-19.92 * * *$ & 2.63 & -1.105 & $-4.696^{*}$ \\
\hline School size & -2.063 & -2.972 & -0.659 & -3.392 & -2.139 & -0.342 & $-9.891 * *$ & $-18.81 * * *$ & -0.469 & $-5.210 *$ & -2.069 & 0.129 \\
\hline Student-teacher ratio & 0.289 & -1.49 & -0.0922 & 0.818 & 2.395 & -0.822 & -1.005 & -5.271 & -1.44 & 0.0541 & -2.325 & 1.241 \\
\hline Computer availability & 0.309 & $-18.62 * * *$ & -2.046 & -0.00833 & 0.0868 & -0.388 & -3.054 & 0.334 & 0.732 & -3.254 & $-7.290 * *$ & -1.052 \\
\hline Internet availability & -0.959 & -0.00974 & 0.00653 & -2.563 & -0.4 & -1.073 & -2.03 & -0.489 & $-6.003 *$ & -4.185 & -0.0349 & 0.035 \\
\hline Grouped by ability (all) & -0.813 & -0.00362 & -0.0281 & -0.128 & -0.095 & -0.0842 & 1.415 & -2.6 & -0.0783 & -0.503 & -0.752 & -0.756 \\
\hline Grouped by ability (some) & 0.169 & -0.529 & -0.0748 & -1.352 & -1.274 & -0.629 & 0.143 & 2.958 & -0.566 & -0.0487 & -1.947 & -0.825 \\
\hline Quality of educational resources & -0.595 & 0.195 & -0.546 & 1.073 & -1.552 & -2.153 & -2.323 & $-15.68 * *$ & $-18.34 * * *$ & $-8.066 * * *$ & -0.124 & -0.798 \\
\hline Science promotion & -0.733 & -1.164 & -1.534 & -0.0249 & -0.473 & $-13.26 * * *$ & $-8.775 * *$ & -2.502 & -1.375 & $-5.864 * * *$ & $-6.759 *$ & 0.136 \\
\hline Responsibility for curriculum & 2.772 & 0.1 & -0.102 & -0.301 & 0.0996 & 0.226 & -0.424 & -1.583 & $-3.651 *$ & $-2.572 * *$ & -0.0849 & 0.598 \\
\hline Responsibility for resources & 0.681 & -2.065 & 0.532 & 0.361 & -0.078 & -0.95 & 0.423 & 1.503 & -0.782 & $-7.132 * *$ & -1.368 & 0.024 \\
\hline
\end{tabular}




\begin{tabular}{|c|c|c|c|c|c|c|c|c|c|c|c|c|}
\hline Academic admission criteria always applied & 0.933 & -0.245 & 0.701 & -1.239 & -0.626 & -1.663 & -0.561 & 0.781 & 0.372 & 0.739 & 0.794 & -0.0158 \\
\hline Academic admission criteria sometimes applied & -0.706 & 1.645 & 0.231 & -0.357 & 0.563 & 0.176 & -1.205 & -0.283 & -2.367 & $-4.566 * *$ & 1.655 & -1.118 \\
\hline Academic admission criteria as prerequisite & -2.241 & -0.615 & -3.079 & -3.249 & -0.512 & $-14.83 * *$ & -1.508 & -0.331 & -3.464 & -1.654 & -5.72 & $-10.46 * * *$ \\
\hline Teacher variables & $-2.554 * *$ & $-3.684 * * *$ & $-7.034 * * *$ & $-13.37 * * *$ & $-5.849 * * *$ & $-3.012 * *$ & $-3.230 *$ & 0.000956 & -2.600 & $-3.872 * * *$ & $-4.705 * * *$ & $-3.591 * * *$ \\
\hline Interactive teaching in science & -0.306 & 0.177 & -0.153 & 1.679 & -0.11 & -0.192 & -1.204 & 0.672 & 0.942 & -0.192 & -0.646 & 0.228 \\
\hline Applications in science & $-1.541 * *$ & -0.374 & -0.293 & 0.494 & 0.173 & -0.129 & -0.161 & -0.314 & $-3.605 * * *$ & $-1.573 *$ & $-5.381 * * *$ & -0.947 \\
\hline Hands-on activities in science & -0.654 & 0.221 & -1.049 & -1.434 & -0.82 & -0.949 & -0.313 & -0.754 & $2.306^{*}$ & 0.672 & 0.673 & -0.596 \\
\hline Investigations in science & -0.0534 & $-3.708 * * *$ & $-5.540 * * *$ & $-14.11 * * *$ & $-5.092 * * *$ & $-1.741 *$ & -1.552 & 0.397 & -2.243 & $-2.779 * *$ & 0.648 & $-2.276 * * *$ \\
\hline
\end{tabular}

Note: $*$ Significant at the $10 \%$ level. $* *$ Significant at the $5 \%$ level. *** Significant at the $1 \%$ level. 
Table 1: Oaxaca-Blinder decomposition between high ESCS (q75) and low ESCS (q25) students in scores for science in 2006 and reading in 2009. Detailed results for the explained component (2/2).

\begin{tabular}{|c|c|c|c|c|c|c|c|c|c|c|c|c|}
\hline Reading 2009 & JOR & TUN & AZE & KGZ & RUS & TUR & IDN & THA & BRA & MEX & NLD & GBR \\
\hline ESCS25 & 396.5 & 374.8 & 358.3 & 291.3 & 432.3 & 439.3 & 397.7 & 407.3 & 400.5 & 405.2 & 481.5 & 458.2 \\
\hline \multirow[t]{2}{*}{ ESCS75 } & 455 & 445 & 403.9 & 392.6 & 507.2 & 516.2 & 438.8 & 474.5 & 485.6 & 482.1 & 557.6 & 547.7 \\
\hline & & & & & & & & & & & & - \\
\hline Difference & $-58.54 * * *$ & $-70.21 * * *$ & $-45.63 * * *$ & $-101.3 * * *$ & $-74.90 * * *$ & $-76.85 * * *$ & $-41.08 * * *$ & $-67.19 * * *$ & $-85.19 * * *$ & $-76.94 * * *$ & $-76.15 * * *$ & $89.54 * * *$ \\
\hline \multirow[t]{3}{*}{ Unexplained } & $-49.29 * * *$ & $-48.58 * * *$ & $-19.64 * * *$ & $-56.10^{* * *}$ & $-56.52 * * *$ & $-48.30 * * *$ & $-10.68^{*}$ & $-14.68^{* *}$ & $-37.73^{* * *}$ & $-38.06^{* * *}$ & $-40.44^{* * *}$ & - \\
\hline & & & & & & & & & & & & $71.39^{* * *}$ \\
\hline & & & & & & & & & & & & - \\
\hline Explained & -9.259 & $-21.62 * *$ & $-25.99 * * *$ & $-45.19 * * *$ & $-18.38 * * *$ & $-28.55 * * *$ & $-30.41 * * *$ & $-52.51 * * *$ & $-47.46^{* * *}$ & $-38.87 * * *$ & $-35.71 * * *$ & $18.14 * * *$ \\
\hline Individual variables & 2.654 & $-2.793 *$ & -1.892 & 0.823 & -3.566 & $-9.094 * * *$ & -0.443 & $-10.87 * * *$ & -1.084 & $-4.571 * * *$ & -2.263 & -4.828 \\
\hline Female & 2.340 & 0.454 & 0.00846 & 0.693 & 1.267 & $-2.035^{* *}$ & $2.285^{*}$ & $2.786^{* *}$ & $1.438^{* *}$ & $1.323 * *$ & 0.891 & -0.110 \\
\hline Age & -0.0738 & -0.156 & 0.0723 & 0.000863 & 0.0773 & -0.00102 & 0.00231 & -0.00445 & -0.0320 & -0.113 & -0.131 & 0.0872 \\
\hline Immigrant 1st gen. & 0.219 & 0.0756 & 0.0416 & -0.0186 & -0.316 & -0.0210 & 0.119 & 0 & -0.00526 & -0.0932 & 0.829 & -0.316 \\
\hline Immigrant 2nd gen. & -0.645 & 0.0165 & 0.140 & -0.177 & $-1.167^{*}$ & 0.0785 & 0 & 0 & -0.461 & $-0.811^{*}$ & -3.210 & -0.160 \\
\hline Single parent & -0.836 & -0.125 & -0.0446 & 0.140 & 0.819 & 0.0849 & -0.240 & 0.00156 & -0.0558 & -0.215 & -1.243 & -1.554 \\
\hline Other family type & -0.925 & $-3.178 * * *$ & 0.395 & -0.685 & -0.638 & $-3.937 * * *$ & $-1.373^{*}$ & $-5.275^{* * *}$ & $-1.941 * *$ & $-1.184 * * *$ & -0.254 & $-1.832 *$ \\
\hline Language & $2.902^{* *}$ & 0.0970 & $-2.203^{*}$ & 1.249 & -3.623 & -1.104 & -0.803 & $-8.411 * *$ & 0.0139 & -0.663 & 0.998 & -0.976 \\
\hline \multirow[t]{2}{*}{ Attitude toward school } & -0.329 & 0.0225 & -0.302 & -0.380 & 0.0149 & $-2.160^{* *}$ & -0.433 & 0.0328 & -0.0407 & $-2.815^{* * *}$ & -0.145 & 0.0322 \\
\hline & $-10.32 *$ & $-18.96^{* *}$ & $-23.44 * * *$ & $-45.31 * * *$ & $-14.07 * *$ & $-17.88 * * *$ & $-28.33 * * *$ & $-40.56^{* * *}$ & $-44.79 * * *$ & $-33.57 * * *$ & $-32.68 * * *$ & - \\
\hline School variables & & & & & & & & & & & & $6.962^{* * *}$ \\
\hline Rural & -2.335 & -1.634 & -9.634 & $-16.16^{* * *}$ & -6.687 & -3.183 & $-5.478^{*}$ & -6.972 & 2.455 & $-8.722 * * *$ & -1.363 & -0.0501 \\
\hline Private & $-4.291 *$ & 1.226 & 0.0405 & -5.105 & -0.000122 & -6.120 & 0.0379 & $3.398^{*}$ & $-27.05^{* *}$ & $-4.654 *$ & 0.170 & -2.374 \\
\hline School size & -1.405 & $-13.17 * * *$ & -9.967 & -12.29 & $-12.14^{* * *}$ & -1.718 & -4.334 & $-28.39 * * *$ & -1.519 & $-4.627 * * *$ & $-9.391 * * *$ & -1.139 \\
\hline Student-teacher ratio & 0.825 & -1.167 & -0.310 & 0.358 & $4.629 * *$ & $-2.287 *$ & 0.990 & -1.154 & -3.008 & 0.0445 & $-13.87 *$ & 0.0257 \\
\hline Computer availability & 0.615 & -1.630 & -2.117 & -2.874 & 0.441 & -2.049 & -2.115 & -0.0379 & 0.418 & -0.0473 & 0.00773 & 0.346 \\
\hline Internet availability & 1.112 & -4.275 & -2.740 & 3.627 & -0.0845 & 0.0230 & $-9.853 * *$ & -0.837 & -1.253 & -0.438 & 0.333 & -0.0165 \\
\hline
\end{tabular}




\begin{tabular}{|c|c|c|c|c|c|c|c|c|c|c|c|c|}
\hline Grouped by ability (all) & 0.513 & -0.750 & 3.109 & -0.708 & -0.560 & 0.0284 & -1.507 & $-2.620 *$ & 0.167 & -0.0823 & -1.257 & -0.614 \\
\hline \multirow[t]{2}{*}{ Grouped by ability (some) } & -0.832 & 0.707 & -1.612 & -0.0136 & -0.216 & 0.155 & -0.356 & -0.752 & -0.228 & 0.786 & -1.698 & 0.198 \\
\hline & & & & & & & & & & & & - \\
\hline Quality of educational resources & -1.077 & 0.157 & -0.0433 & -3.209 & -1.011 & -0.0216 & -1.570 & -1.087 & -5.304 & $-10.73 * * *$ & 2.304 & 0.000231 \\
\hline Extra-curricular activities & $-5.461 * *$ & 1.740 & -0.163 & -0.643 & $3.181 * *$ & -3.190 & -3.567 & -0.643 & $-6.666^{* *}$ & $-2.802 *$ & $-8.794 * *$ & 0.375 \\
\hline Principal's leadership & 0.114 & -0.936 & 0.0739 & -4.842 & 0.293 & 0.761 & 0.328 & -2.271 & -0.943 & 3.335 & 0.118 & -0.233 \\
\hline Responsibility for curriculum & $3.568 * *$ & 0.530 & 0.0528 & -1.148 & 0.714 & 0.119 & -0.691 & 0.699 & -2.557 & -1.492 & -0.167 & -0.437 \\
\hline Responsibility for resources & 4.360 & 0.647 & -0.140 & -1.825 & 0.412 & 5.497 & 0.194 & 0.324 & 1.548 & 1.042 & 0.187 & -0.272 \\
\hline Academic admission criteria always applied & -1.695 & 0.000248 & 0.00915 & 0.0237 & -0.200 & 0.866 & 0.484 & -0.214 & -1.107 & -0.164 & 0.733 & -0.913 \\
\hline \multirow[t]{2}{*}{ Academic admission criteria sometimes applied } & -4.335 & -0.406 & 0.00377 & -0.497 & -2.842 & $-6.756 * *$ & -0.892 & -0.00514 & 0.265 & $-5.018 *$ & 0 & -1.857 \\
\hline & -1.590 & 0.133 & -0.656 & -0.707 & -0.744 & $-1.583 *$ & $-1.635^{* *}$ & $-1.080 *$ & -1.590 & -0.734 & -0.764 & - \\
\hline \multirow[t]{2}{*}{ Teacher variables } & & & & & & & & & & & & $6.355^{* * *}$ \\
\hline & & & & & & & & & & & & - \\
\hline Teacher-student relations & 0.196 & 0.280 & -0.190 & -0.0282 & -0.576 & 0.212 & -0.453 & -0.0528 & 0.124 & -0.153 & -0.154 & $2.457 * * *$ \\
\hline Disciplinary climate & 0.337 & 0.224 & -0.668 & -0.972 & -0.0263 & -0.353 & -0.107 & 0.274 & -0.532 & $0.462 * *$ & -0.114 & -1.533 \\
\hline Stimulus to read & $-2.097 * *$ & -0.407 & 0.167 & 0.317 & -0.254 & $-1.425^{* *}$ & -0.186 & $-1.392 * * *$ & -0.336 & $-1.015^{* * *}$ & 0.297 & $-1.923^{*}$ \\
\hline Motivating questions & -0.0250 & 0.0369 & 0.0343 & -0.0229 & 0.113 & -0.0170 & $-0.889^{*}$ & 0.0911 & -0.846 & -0.0275 & -0.793 & -0.441 \\
\hline
\end{tabular}

Note: ${ }^{*}$ Significant at the $10 \%$ level. ${ }^{* *}$ Significant at the $5 \%$ level. $* * *$ Significant at the $1 \%$ level. 


\section{Appendix}

Table A.1 Variable definition (1/2)

\begin{tabular}{|c|c|}
\hline Variable & Definition \\
\hline \multicolumn{2}{|l|}{ Individual variables: } \\
\hline Score & Mean score for reading in 2006 and science in 2009 \\
\hline Female & Dummy variable: 1 if female, 0 if male \\
\hline Age & Age of student \\
\hline Immigrant 1st gen. & $\begin{array}{l}\text { Dummy variable: } 1 \text { if first-generation students (those born outside the country of assessment } \\
\text { whose parents were also born in another country), } 0 \text { if native students. }\end{array}$ \\
\hline Immigrant 2nd gen. & $\begin{array}{l}\text { Dummy variable: } 1 \text { if second-generation students (those born in the country of assessment } \\
\text { whose parents were born in another country), } 0 \text { if native students }\end{array}$ \\
\hline Language & $\begin{array}{l}\text { Dummy variable: } 1 \text { if language at home is a different language than the language of } \\
\text { assessment, } 0 \text { if language at home is the same as the language of assessment }\end{array}$ \\
\hline $\begin{array}{l}\text { Single parent } \\
\text { Other family type (2009) }\end{array}$ & $\begin{array}{l}\text { Dummy variable: } 1 \text { if single-parent family, } 0 \text { if two-parent family } \\
\text { Dummy variable: } 1 \text { if other type of family, } 0 \text { if two-parent family }\end{array}$ \\
\hline Interest in science (2006) & $\begin{array}{l}\text { Index of general interest in science learning. Positive scores indicate higher levels of interest in } \\
\text { learning science. }\end{array}$ \\
\hline Attitude toward school (2009) & $\begin{array}{l}\text { Index of attitude toward school. Higher values on this index indicate perception of a more } \\
\text { positive school climate. }\end{array}$ \\
\hline \multicolumn{2}{|r|}{ P } \\
\hline Rural & $\begin{array}{l}\text { Dummy variable: } 1 \text { if school is located in a community with under } 15,000 \text { people, } 0 \text { if the } \\
\text { community has over } 15,000 \text { people }\end{array}$ \\
\hline Private & Dummy variable: 1 if private school, 0 if public school \\
\hline School size & Number of girls and boys at a school \\
\hline Student-teacher ratio & Student-teacher ratio was obtained by dividing the school size by the total number of teachers. \\
\hline Computer availability & Index of computer availability \\
\hline Internet availability & Index of computers connected to the Internet \\
\hline Grouped by ability (all) & $\begin{array}{l}\text { Dummy variable: } 1 \text { if schools group students by ability in all subjects, } 0 \text { if schools do not } \\
\text { group students by ability in any subjects }\end{array}$ \\
\hline Grouped by ability (some) & $\begin{array}{l}\text { Dummy variable: } 1 \text { if schools group students by ability for some, but not all, subjects; } 0 \text { if } \\
\text { schools do not group students by ability in any subjects. }\end{array}$ \\
\hline Quality of educational resources & $\begin{array}{l}\text { Index on the school's educational resources. Higher values on this index indicate better quality } \\
\text { of educational resources. }\end{array}$ \\
\hline Science promotion (2006) & $\begin{array}{l}\text { School principals are asked to report what activities their school offers to promote students' } \\
\text { learning of science. Positive scores indicate higher levels of school activities in this area. }\end{array}$ \\
\hline Extra-curricular activities (2009) & $\begin{array}{l}\text { Index of extra-curricular activities. Higher values on the index indicate higher levels of extra- } \\
\text { curricular school activities. }\end{array}$ \\
\hline Principal's leadership (2009) & $\begin{array}{l}\text { Index of school principal's leadership. Higher values on this index indicate greater } \\
\text { involvement of school principals in school affairs. }\end{array}$ \\
\hline Responsibility for curriculum & $\begin{array}{l}\text { Index of responsibility for curriculum and assessment. Positive values on this index indicate } \\
\text { relatively more responsibility for schools than local, regional, or national education authority. }\end{array}$ \\
\hline Responsibility for resources & $\begin{array}{l}\text { Index of responsibility for resource allocation. Positive values on this index indicate relatively } \\
\text { more responsibility for schools than local, regional, or national education authority. }\end{array}$ \\
\hline $\begin{array}{l}\text { Academic admission criteria } \\
\text { always applied }\end{array}$ & $\begin{array}{l}\text { Dummy variable: } 1 \text { if schools consider at least one of these factors (SC19Q02-Q03) for } \\
\text { student admittance, } 0 \text { if schools where schools consider none of these factors for student } \\
\text { admittance. }\end{array}$ \\
\hline $\begin{array}{l}\text { Academic admission criteria } \\
\text { sometimes applied }\end{array}$ & $\begin{array}{l}\text { Dummy variable: } 1 \text { if schools give high priority to at least one of these factors (SC19Q02- } \\
\text { Q03), } 0 \text { if schools consider none of these factors for student admittance. }\end{array}$ \\
\hline $\begin{array}{l}\text { Academic admission criteria as } \\
\text { prerequisite (2006) }\end{array}$ & $\begin{array}{l}\text { Dummy variable: } 1 \text { if at least one of these factors (SC19Q02-Q03) is a prerequisite for student } \\
\text { admittance, } 0 \text { if none of these factors is considered for student admittance. }\end{array}$ \\
\hline
\end{tabular}


Table A.1 Variable definition (2/2)

\begin{tabular}{|c|c|}
\hline Variable & Definition \\
\hline $\begin{array}{l}\text { Academic admission criteria always } \\
\text { applied }\end{array}$ & $\begin{array}{l}\text { Dummy variable: } 1 \text { if at least one of these two factors (SC19Q02-Q03) related to student's } \\
\text { academic records or placement tests is always considered for student admittance, } 0 \text { if these } \\
\text { two factors are never considered for admittance. } \\
\text { Dummy variable: } 1 \text { if schools sometimes consider at least one of these two factors } \\
\text { (SC19Q02-Q03) related to student's academic records or placement tests, but neither factor } \\
\text { always; } 0 \text { if schools never consider these two factors for student admittance. }\end{array}$ \\
\hline \multicolumn{2}{|r|}{ 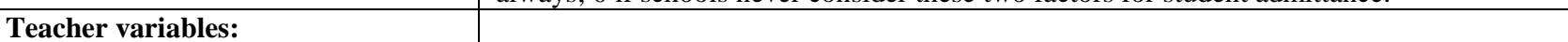 } \\
\hline Interactive teaching in science (2006) & $\begin{array}{l}\text { Index of the frequency of interactive teaching in science lessons. Positive scores on this } \\
\text { index indicate higher frequencies of interactive science teaching. }\end{array}$ \\
\hline Applications in science (2006) & $\begin{array}{l}\text { Index of the frequency of teaching in science lessons with a focus on applications. Positive } \\
\text { scores on this index indicate higher frequencies of this type of science teaching. }\end{array}$ \\
\hline Hands-on activities in science (2006) & $\begin{array}{l}\text { Index of the frequency of hands-on activities in science lessons. Positive scores on this } \\
\text { index indicate higher frequencies of this type of science teaching. }\end{array}$ \\
\hline Investigations in science (2006) & $\begin{array}{l}\text { Index of the frequency of student investigations in science lessons. Positive scores on this } \\
\text { index indicate perceived higher frequencies of this type of science teaching. }\end{array}$ \\
\hline Teacher-student relations (2009) & $\begin{array}{l}\text { Index of teacher-student relations. Higher values on this index indicate positive teacher- } \\
\text { student relations. }\end{array}$ \\
\hline Disciplinary climate (2009) & $\begin{array}{l}\text { Index of disciplinary climate. Higher values on this index indicate a better disciplinary } \\
\text { climate. }\end{array}$ \\
\hline Stimulus to read (2009) & $\begin{array}{l}\text { Dummy variable: } 1 \text { if student answered "in most lessons" or "in all lessons" to the item } \\
\text { Q37_a, "the teacher asks students to explain the meaning of a text", } 0 \text { if student answered } \\
\text { "Never or hardly ever" or "in some lessons". }\end{array}$ \\
\hline Motivating questions (2009) & $\begin{array}{l}\text { Dummy variable: } 1 \text { if student answered "in most lessons" or "in all lessons" to the item } \\
\text { Q38_g, "the teacher gives students the chance to ask questions about the reading } \\
\text { assignment", } 0 \text { if student answered "Never or hardly ever" or "in some lessons". }\end{array}$ \\
\hline
\end{tabular}

